„Przekłady Literatur Słowiańskich”. T. 11, cz. 1, s. 1-23

ISSN 2353-9763 (wersja elektroniczna)

DOI https://doi.org/10.31261/PLS.2021.11.01.08

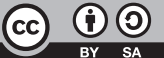

\title{
Tako rzecze Zaratustra Wacława Berenta: młodopolska maniera czy nowatorski eksperyment?
}

\author{
Wacław Berent's Tako rzecze Zaratustra \\ (Translation of Friedrich Nietzsche's \\ Also sprach Zarathustra): Young-Poland-Mannerism \\ or an Innovative Experiment?
}

\author{
Katarzyna Lukas \\ iD https://orcid.org/0000-0003-0632-8966 \\ UNIVERSITY OF GDAŃSK \\ katarzyna.lukas@ug.edu.pl \\ Data zgłoszenia: 17.02.2021 r. ～Data akceptacji: 26.04.2021 r.

\begin{abstract}
The paper deals with the Polish translation of Friedrich Nietzsche's Also sprach Zarathustra made by the Polish writer Wacław Berent (1905). The translation is considered in the context of its epoch ("Young Poland") and of Berent's own literary work. The analysis aims at distinguishing the most important stylistic features of the translation: poetic devices typical of Young Poland, such as archaisms, neologisms, and reinforcement of the original's audial qualities. Despite being criticized as "mannerist", Berent's translation appears as an innovative example of modernist translation, consistent with the symbolist model of translation.
\end{abstract}

KEYWORDS | translation, Young Poland, archaism, Friedrich Nietzsche, Wacław Berent 
Twórczość Fryderyka Nietzschego (1844-1900) była, obok dzieł Schopenhauera i Bergsona, najważniejszym źródłem inspiracji filozoficznych w literaturze Młodej Polski. Z pism takich, jak Poza dobrem i złem, Wola mocy, Ludzkie, arcyludzkie, a przede wszystkim Tako rzecze Zaratustra (Also sprach Zarathustra, $1883-1885^{1}$ ) wywodzono aktywizm i kult „nadczłowieka”: jednostki twórczej, dążącej do wolności i potęgi, realizującej „wolę mocy” i bezwzględne wartości życia, odrzucającej religię i tradycyjną moralność. Artystom Młodej Polski bliski był nietzscheański ideał homo creator oraz koncepcja „sztuki przezwyciężającej rozpacz istnienia”². Postulaty twórczości, woli, czynnego współkształtowania historii legły u podstaw estetycznego programu epoki. Wykładnia historiozoficzna myśli Nietzschego, odczytywanej w Młodej Polsce przez pryzmat dramatów Słowackiego, oraz włączenie nietzscheanizmu - po roku 1905 - w kontekst rewolucji i ideologii socjalistycznej pomogło stworzyć filozoficzną podbudowę dla polskich dążeń niepodległościowych ${ }^{3}$.

Pisma niemieckiego filozofa wprowadzano w polski obieg czytelniczy pod koniec lat 80. XIX wieku w postaci omówień w prasie oraz tłumaczonych fragmentów. Lata 1905-1912 przyniosły polskie wydanie zbiorowe jego dzieł: 13-tomową ${ }^{4}$ edycję Mortkowicza. Tłumaczenia do niej sporządzili Wacław Berent, Leopold Staff, Stanisław Wyrzykowski, Konrad Drzewiecki i Stefan Frycz. Wydanie to ukształtowało w polskiej tradycji obraz Nietzschego aktualny do dziś. Obecność autora Zaratustry w polskiej kulturze jest rezultatem jego recepcji w Młodej Polsce, a ówczesne przekłady stanowią punkt odniesienia dla wszystkich późniejszych retranslacji ${ }^{5}$. Dotyczy to zwłaszcza tłumaczenia Also sprach Zarathustra, otwierającego edycję Mortkowicza (1905). Dla czytelników polskich jest to bodaj najbardziej znane dzieło niemieckiego filozofa, a nadany mu przez Berenta niezwykły tytuł - Tako rzecze Zaratustra - wrósł w literacką polszczyznę. Choć polska seria przekładowa utworu obejmuje dziś już cztery translacje ${ }^{6}$, to właśnie tłumaczenie Berenta wciąż można określić jako kano-

1 Utwór składa się z czterech części, z których każda była publikowana osobno w latach 1883-1885. Jako całość wszystkie cztery części ukazały się po raz pierwszy w roku 1893.

2 A.Z. Makowiecki, 1992: Młoda Polska. W: A. Brodzka et al., red.: Słownik literatury polskiej XX wieku. Wrocław-Warszawa-Kraków, Zakład Narodowy im. Ossolińskich, s. 651-664, tu: s. 654.

3 Por. M. Kopij, 2005: Friedrich Nietzsche $w$ literaturze i publicystyce polskiej lat 18831918. Struktura recepcji. Poznań, Wydawnictwo Poznańskie, s. 138, 258-259.

4 Podaję za: M. Kopij, 2005: Friedrich Nietzsche w literaturze..., s. 202, przypis 234 oraz s. 206.

5 Zob. ibidem, s. 259.

6 Tłumaczenie Berenta (1905) poprzedziła w roku 1901 wersja Marii Cumft-Pieńkowskiej i Stanisława Pieńkowskiego Tak mówił Zaratustra. Objęła ona jednak tylko 
niczne - nie tylko ze względu na tytuł, lecz także indywidualną poetykę translatorską, tyleż oryginalną, co kontrowersyjną już dla współczesnych Berentowi. Komentatorzy młodopolscy zarzucali tłumaczowi młodopolskie zmanierowanie, chybioną archaizację biblijną, fałszywy patos, a także (po części słusznie) banalne błędy słownikowe. Symptomatyczna jest tu ocena Stanisława Pieńkowskiego - choć złośliwa, bo podyktowana urażoną ambicją autora konkurencyjnego przekładu, to reprezentatywna dla większości krytyków: Berent sili się „na niezwykłość, sztuczność, na niby-starą polszczyznę - w języku, oraz na nienaturalny, karkołomny i nielogiczny szyk słów - w stylu"7. Uważano, że Tako rzecze Zaratustra przeinacza sens oryginału. Do dziś panuje opinia, że Berent nie oddał adekwatnie warstwy filozoficznej oryginału ${ }^{8}$, ponieważ nie rozpoznał znaczenia wielu nietzscheańskich słów kluczy (np. Untergang, Grund, Gleichnis, $\operatorname{Sinn})^{9}$ i uciekał się do synonimów zamiast jednolicie stosowanych ekwiwalentów ${ }^{10}$. Specyficzna młodopolska maniera zaciemnia stylizacyjne walory tekstu niemieckiego ${ }^{11}$ i powoduje, że obecnie dla czytelnika polskiego przekład Berenta brzmi dużo mniej zrozumiale niż poetycka proza Nietzschego dla współczesnych odbiorców niemieckich. Mimo tych zastrzeżeń translacja dokonana przez autora Próchna wciąż urzeka swym pięknem, cieszy się uznaniem i szacunkiem obecnych tłumaczy ${ }^{12}$. Co zadecydowało o tak wysokiej randze Tako rzecze Zaratustra w polskim kanonie literatury tłumaczonej? Moim zdaniem przekład ten broni się jako ponadczasowy językowy eksperyment, którego autor wybiórczo i krytycznie korzysta z różnych wzorców stylistycznych, nie podporządkowując się żadnej tradycji translatorskiej. Źródła, z których czerpie tłumacz - co

pierwszą z czterech części tekstu Nietzschego. Wkrótce wyeliminowała ją z obiegu kompletna wersja Berenta, która do lat 20. XX wieku doczekała się kilku wydań, a po roku 1990 - licznych reprintów. Dopiero u progu kolejnego stulecia ukazały się dwa nowe przekłady: To rzekł Zaratustra Sławy Lisieckiej i Zdzisława Jaskuły (1999) oraz Tak mówił Zaratustra Grzegorza Sowinskiego (2005).

7 S. Pieńkowski, 1922: Nie tak mówił Zaratustra. „Gazeta Warszawska”, nr 239, s. 5-6, tu: s. 5.

8 Zob. S. Lisiecka, 2000: Rozmowa 1: O czytaniu Nietzschego. „Tytuł”, z. 4, s. 70-76, tu: s. 73.

9 Zob. S. Lisiecka, Z. Jaskuła, 1999: Od tłumaczy. W: F. Nietzsche: To rzekł Zaratustra. Ksiązka dla wszystkich i dla nikogo. S. Lisiecka, Z. Jaskuła, tłum. Warszawa, PIW, s. $431-435$.

10 Zob. T. Rajewicz, 2005: Stylizacja biblijna „Zaratustry” Friedricha Nietzschego w przekładach na język polski. W: Język trzeciego tysiąclecia 3: zbiór referatów $z$ konferencji, Kraków, 4-7.03.2004. T. 2: M. Piotrowska, red.: Konteksty przekładowe. Kraków, Tertium, s. 99-106, tu: s. 105.

11 Zob. S. Lisiecka, Z. Jaskuła, 2000: Między filologią a filozofią. O tłumaczeniu „Zaratustry” Nietzschego. „Tytuł”, z. 4, s. 54-69, tu: s. 55.

12 Zob. S. Lisiecka, Z. Jaskuła, 1999: Od tłumaczy..., s. 435. 
postaram się pokazać w artykule — to trzy kody językowo-literackie, częściowo zachodzące na siebie: styl Młodej Polski, indywidualna poetyka Berenta oraz język Biblii jako wzorzec archaizacyjny. Nowatorski charakter polskiego Zaratustry najwyraźniej widać w zestawieniu ze współczesnym mu, lecz krańcowo odmiennym przekładem Marii i Stanisława Pieńkowskich.

\section{Nietzsche, Berent i Młoda Polska: powinowactwa idei i stylu}

Nietzsche nie stworzył spójnego, jednolitego systemu filozoficznego jak Kant czy Schopenhauer, jego pismom brak cech typowych dla rozpraw filozoficznych, a koncepcje potrafią wykluczać się wzajemnie nawet w obrębie jednego tekstu ${ }^{13}$. W Niemczech postrzegano Nietzschego zrazu jako poetę, dopiero Heidegger zapoczątkował tradycję lektury jego dzieł w kluczu filozoficznym. Dziś podkreśla się hybrydyczny charakter tych pism, ich przynależność jednocześnie do filozofii (dyskursu dążącego do precyzji wywodu i jasności terminologicznej) i literatury (domeny języka poetyckiego: metaforycznego, stroniącego od jednoznaczności, poszerzającego pole interpretacji ugruntowanych pojęć). Formuła wielogatunkowej poetyckiej prozy, przechodzącej w Also sprach Zarathustra w filozoficzny wywód, okazała się Berentowi na tyle bliska, że sam wykorzystał ją w Próchnie.

Pod względem budowy dzieło Nietzschego nawiązuje do czterech Ewangelii Nowego Testamentu. Wzorem Pisma Świętego zawiera monologi w formie kazań i przypowieści tytułowego bohatera, fragmenty narracyjne, aforyzmy, powiedzenia, przysłowia, hymny i pieśni liryczne ${ }^{14}$. Na potrzeby utworu niemiecki filozof wykreował specyficzny idiolekt. Cechuje go żonglerka słowna, zdania na przemian długie i krótkie, niedopowiedzenia i nietypowa interpunkcja. „Książka dla wszystkich i dla nikogo” zawiera wiele odniesień stylizacyjnych: biblijnych (do Biblii w przekładzie Marcina Lutra) ${ }^{15}$,

13 Zob. Ł.M. Plęs, 2012: Friedrich Nietzsche - Dichter oder Denker? „Acta Universitatis Lodziensis. Folia Germanica", nr 8, s. 36-49, tu: s. 36, 39.

14 Zob. M.H. Kaulhausen, 1977: Nietzsches Sprachstil: gedeutet aus seinem Lebensgefühl und Weltverhältnis. München-Wien, Oldenbourg, s. 121.

15 O stylizacji biblijnej Nietzschego zob. T. Rajewicz, 2002: Dzieło i przekład w czasie. O języku polskich przekładów dzieła Fryderyka Nietzschego „Also sprach Zarathustra”. „Recepcja - Transfer - Przekład”, t. 1, s. 127-140; T. Rajewicz, 2005: Stylizacja biblijna „Zaratustry” Friedricha Nietzschego...; Ł.M. Plęs, 2010: Die biblischen sowie pseudobiblischen Seligpreisungen in "Also sprach Zarathustra” im Spiegel der Übersetzungsversuche ins Polnische und Englische. „Acta Universitatis Lodziensis. Folia Germanica", nr 6, s. 95-107. 
literackich (Faust Goethego, Hyperion Hölderlina), filozoficznych (Schopenhauer i francuscy moraliści), muzycznych (Wagner). Zastosowany język obfituje w neologizmy, gry słowne, aliteracje, paronomazje i inne figury retoryczne; charakteryzuje się kunsztownym uformowaniem warstwy brzmieniowej ${ }^{16}$. Wszechstronne wykorzystanie walorów niemczyzny odzwierciedla poglądy Nietzschego na język: stanowił on dla twórcy Zaratustry nie tyle narzędzie codziennej komunikacji (język zredukowany do tej funkcji to „skamieniałe słowa”, które „zawalają drogę ${ }^{\text {"17 }}$ ), ile „materię dźwiękową, [w której] przejawia się rytm jako siła dionizyjska"18. Natomiast meliczność i instrumentacja głoskowa są w Also sprach Zarathustra „próbą powiązania sfery wyobrażeniowej ze sferą językową poprzez dźwięk"19. Nietrudno dostrzec zbieżność tych przekonań z modernistyczną filozofią języka: wzrastającą świadomością jego medialności i pozornego mimetyzmu, oraz z młodopolskim programem estetycznym. Istotnym elementem tego programu był „kult słowa” i stworzenie nowego języka poetyckiego, w którym tradycyjne chwyty artystyczne ulegną rewitalizacji między innymi dzięki dążeniu do identyfikacji znaku i desygnatu ${ }^{20}$. Moderniści, odczuwając dychotomię między skonwencjonalizowanym językiem potocznym a słowem poetyckim, zabiegali o dezautomatyzację i odnowę „zużytego" języka. W tym celu młodopolanie uniezwyklali język poetycki, wzbogacając go o neologizmy, dialektyzmy, barbaryzmy czy też archaizmy ${ }^{21}$. Częsty zabieg polegał na włączaniu w obieg dawnych, zapomnianych słów, na używaniu wyrazów w niegdysiejszych, utraconych znaczeniach bądź też na ich „odmładzaniu” przez dodanie nowych prefiksów i sufiksów ${ }^{22}$. Analogiczne chwyty znajdujemy w Also sprach Zarathustra, w którym autor obficie korzysta $\mathrm{z}$ różnorodnych strategii słowotwórczych, a w paronomazjach aktualizuje etymologię wyrazów i ujawnia ich wzajemne nieoczywiste związki.

16 O muzyczności języka Zaratustry zob. Ł.M. Plęs, 2012: F. Nietzsche - Dichter oder Denker?..., s. 43.

17 Taką refleksję Nietzschego zawartą w jego Jutrzence przywołuje R. Nycz, 1997: Homo irrequietus. Nietzscheanizm w twórczości Wacława Berenta. W: Idem: Język modernizmu. Prolegomena historycznoliterackie. Wrocław, Leopoldinum, s. 263-312, tu: s. $62-63$.

18 M. Cieszkowski, 2004: „Tako rzecze Zaratustra” czy „To rzekł Zaratustra” - uwag kilka o polskich tłumaczeniach niepokornego tekstu. „Recepcja - Transfer - Przekład”, t. 2, s. 109-120, tu: s. 119.

19 Ibidem, s. 118.

20 Zob. M. Podraza-Kwiatkowska, 1975: Symbolizm i symbolika w poezji Młodej Polski. Kraków, Wydawnictwo Literackie, s. 299.

21 Zob. ibidem, s. 302; R. Nycz, 1997: Język modernizmu..., s. 65.

22 Zob. M. Podraza-Kwiatkowska, 1975: Symbolizm i symbolika..., s. 303. 
Przekładając utwór Nietzschego, Berent dysponował zatem rozległym „zapleczem” w postaci języka poezji Młodej Polski, wyrastającego z modernistycznych poglądów na język. O kształcie Tako rzecze Zaratustra w równym stopniu zadecydowały także powinowactwa między myślą niemieckiego filozofa i sposobem jej wyrażania a twórczością samego Berenta.

Inspiracje nietzscheańskie ${ }^{23} \mathrm{w}$ pisarstwie polskiego prozaika są dobrze rozpoznane. Przybierają one różną postać: metatekstową (omawiany przekład, kilka esejów o niemieckim filozofie), ideową i stylistyczną. Ryszard Nycz wyróżnia wiele problemów proweniencji nietzscheańskiej, które wpłynęły na artystyczny światopogląd Berenta i znalazły wyraz w jego prozie. Próchno i Also sprach Zarathustra łączy krytyczny stosunek do współczesnej kultury, do roli artysty i sztuki w społeczeństwie oraz poszukiwanie wzorca osobowego dla człowieka modernizmu ${ }^{24}$. Postulat twórczej aktywności, konieczność przekroczenia „mostu ku nadczłowiekowi” jako droga wyjścia z niemocy i dekadencji - te wątki przewijają się w dyskusjach bohaterów Próchna, nawet jeśli nie pada w nich nazwisko Nietzschego ${ }^{25}$.

Jerzy Paszek wymienia kilka cech stylistycznych Also sprach Zarathustra, które mają swoje odpowiedniki w twórczości własnej Berenta, przede wszystkim w Próchnie: stylizacja biblijna, sentencjonalność i aforystyczność akapitów-wersetów, instrumentacja dźwiękowa, przewaga monologu oraz jego paraboliczny charakter $^{26}$. Peer Hultberg natomiast identyfikuje w przekładzie Berenta pewne osobliwości gramatyczne i słowotwórcze te same co w Próchnie i Oziminie ${ }^{27}$; nie są one motywowane stylistyką oryginału, można je więc przypisać preferencjom tłumacza manifestującym się w jego twórczości autorskiej. Omówię je po kolei, zastrzegając przy tym, że jednoznaczne przyporządkowanie danego zjawiska do „stylu Młodej Polski”, „idiolektu Berenta” czy też „języka Biblii” nie zawsze jest możliwe, ponieważ na przykład archaizmy należą do wszystkich trzech kodów. W celu uwypuklenia oryginalności i specyfiki rozwiązań translatorskich Berenta przywołam analogiczne fragmenty z polskich wersji Marii i Stanisława Pieńkowskich (1901) i/lub Sławy Lisieckiej i Zdzisława Jaskuły (1999).

23 Hasło to zawężam tu do inspiracji płynących z Also sprach Zarathustra, mając rzecz jasna świadomość, że Berent czerpał także z innych pism niemieckiego filozofa. Miejsce całokształtu filozofii Nietzschego u autora Próchna to osobny problem; odsyłam tu do rozprawy R. Nycza, 1997: Homo irrequietus...

24 Por. R. Nycz, 1997: Homo irrequietus..., s. 268-271.

25 Zob. ibidem; także: P. Hultberg, 1969: Styl wczesnej prozy fabularnej Wacława Berenta. I. Sieradzki, tłum. Wrocław-Warszawa-Kraków, Zakład Narodowy im. Ossolińskich, s. 76-77, przypis 5.

26 Zob. J. Paszek, 1976: Styl powieści Wacława Berenta. Katowice, Uniwersytet Śląski, s. $81-82$.

27 Zob. P. Hultberg, 1969: Styl wczesnej prozy..., s. 208-209. 


\section{Archaizacja i stylizacja biblijna}

Berent eksponuje odwołania Nietzschego do języka Biblii, inne związki intertekstualne czytelne dla odbiorców niemieckich usuwając na plan dalszy. Uznanie stylizacji nawiązującej do Pisma Świętego za dominantę przekładu wymagało sięgnięcia do zasobów polszczyzny biblijnej, której naturalnym źródłem był wówczas przekład Biblii dokonany przez Jakuba Wujka (1599). To stamtąd czerpie Berent archaizmy, których nagromadzenie raziło współczesnych mu odbiorców.

Archaizację zapowiada już sam tytuł Tako rzecze Zaratustra. U Nietzschego Also sprach Zarathustra odsyła do formuły inquit „Jesus sprach”, powtarzającej się w Ewangeliach u Lutra. Berent nie sięga tu jednak po gotowe rozwiązanie to rzekł, które podsuwają polskie przekłady na czele z Biblią Wujka i z którego skorzystali później Lisiecka i Jaskuła. Paradoksalnie, zamiast utartej formuły biblijnej tłumacz decyduje się na frazę dużo bardziej archaiczną: tako jest formą dawną, skróconą w rozwoju historycznym polszczyzny do tak ${ }^{28}$; dziś zachowało się już tylko w wyrażeniu jako tako. $\mathrm{Z}$ tego samego powodu tłumacz wybiera czasownik rzecze w postaci teraźniejszej, silniej nacechowanej dawnością niż rzekł - nawet kosztem odejścia od sygnalizującego literacką narrację czasu przeszłego Präteritum z tytułu Nietzschego. Jak zauważył Hultberg, wśród niezwykle różnorodnych formuł inquit stosowanych w Próchnie czasownik rzec pojawia się wielokrotnie w czasie przeszłym (rzekł), nigdy natomiast jako rze$c z e^{29}$. Nasuwa to przypuszczenie, że Berent tę wyjątkowo archaiczną formę „zarezerwował” dla tłumaczenia tytułu Nietzschego. Ponadto czas teraźniejszy może uniwersalizować przekaz i podkreślać jego ponadczasową wagę, podczas gdy forma rzekł w przekładzie Lisieckiej i Jaskuły sytuuje słowa Zaratustry w odległej przeszłości, sugerując komunikat raz wypowiedziany, który mógł się zdezaktualizować, a nawet ulec dewaluacji.

Archaizacja biblijna obejmuje w Tako rzecze Zaratustra różne zjawiska gramatyczne (fleksję, morfologię, składnię) i leksykalne, wnikliwie opisane przez Tomasza Rajewicza ${ }^{30}$. Do pierwszej grupy należą osobliwości deklinacji, przede wszystkim narzędnik rzeczownika w liczbie mnogiej rodzaju męskiego i nijakiego z końcówką - $y(-i)$ zamiast nowszej - (a)mi. Formy zakończone na $-y(-i)$, już pod koniec XVIII wieku wyparte przez końcówkę dziś używaną ${ }^{31}$, należały

28 Zob. A. Brückner, 1989: Słownik etymologiczny języka polskiego. Warszawa, Wiedza Powszechna, s. 564. Analogicznie jako uległo redukcji do jak, zob. ibidem, s. 197.

29 Zob. P. Hultberg, 1969: Styl wczesnej prozy..., s. 118.

30 Zob. T. Rajewicz, 2002: Dzieło i przekład w czasie..., s. 134-140.

31 Zob. Z. Klemensiewicz, 1999: Historia języka polskiego. Warszawa, PWN, s. 616. 
do ulubionych środków stylizacyjnych w poezji Młodej Polski ${ }^{32}$. Podobnie zaimki i przymiotniki w narzędniku liczby mnogiej otrzymują u Berenta często (choć nie zawsze) końcówkę -emi, np.: „Z zamkniętemi oczy”33, „stokrotnemi zwierciadły” (WB 136), „obwieszony szpetnemi prawdy” (WB 139), „z dzikiemi zwierzęty” (WB 140), „bocznemi skrada się ścieżki i kłamliwemi drogi” (WB 147). Zaimki i przymiotniki w liczbie pojedynczej rodzaju nijakiego również przybierają końcówkę -em zamiast -ym, np.: „naonczas była ta wzgarda czemś najwyższem; chciała mieć dusza ciało chudem, wstrętnem, zagłodzonem” (WB 7-8), „Jakżem umęczony swem złem i dobrem!” (WB 8). Dwa ostatnie przykłady warto porównać z neutralną wersją Pieńkowskich: „wówczas pogarda ta była rzeczą najwyższą; dusza chciała mieć ciało chude, brzydkie i zgłodniałe" ", "Jakże znużony jestem moim dobrem i moim złem!” (CP 19). Należy jednak zauważyć, że Berent stosuje dawne formy fleksyjne wybiórczo, unikając ich kumulacji. Przykładowo, jednym z ulubionych archaizmów młodopolskich była męska forma niezłożona mianownika liczby pojedynczej przymiotników i imiesłowów przymiotnikowych biernych - relikt ich rzeczownikowej odmiany, np. umęczon ${ }^{35}$. Tymczasem Berent w przywołanym zdaniu "Jakżem umęczony swem złem i dobrem!" wybiera nowszą formę umęczony, rezygnując z aluzji do staropolskiego tekstu Składu apostolskiego: „umęczon pod Ponckim Piłatem, ukrzyżowan, umarł i pogrzebion”. Świadczy to o wyczuciu estetycznym tłumacza, który - wbrew zarzutom krytyków - starał się uniknąć stylizacyjnej przesady. Formy złożone przymiotników i imiesłowów pojawiają się na przemian z niezłożonymi, np.: „Błogosław kielich przepełniony, aby złotemi rozpłynął się strugi i twej świetności odblask wszędzie poroznosił. Spojrzyj! kielich ten chce znowu być opróżnion [...]” (WB 4).

Kolejny zabieg archaizacyjny w zakresie fleksji polega na oddzieleniu końcówki osobowej czasownika i dołączeniu jej do innego, zazwyczaj pierwszego wyrazu w zdaniu. Na łączliwość tę podatne są zwłaszcza zaimki i spójniki, niekiedy rzeczowniki i przysłówki, a jej efektem jest podniosły, uroczysty ton wypowiedzi. Widać to wyraźnie w zestawieniu z wersją Pieńkowskich, którzy ten chwyt stosują sporadycznie:

32 Zob. M. Podraza-Kwiatkowska, 1975: Symbolizm i symbolika..., s. 304.

33 F. Nietzsche, 1990: Tako rzecze Zaratustra. Książka dla wszystkich i dla nikogo. W. Berent, tłum. Warszawa, Bis, s. 128. Dalsze cytaty z tej pozycji oznaczam w tekście skrótem WB, po którym podaję numer strony.

34 F. Nietzsche, 1901: Tak mówił Zaratustra. Książka dla wszystkich i dla nikogo. M. Cumft, S. Pieńkowski, tłum. Warszawa, Wydawnictwo Władysława Okręta, s. 18. Dalsze cytaty z tej pozycji oznaczam w tekście skrótem CP, po którym podaję numer strony.

35 Zob. M. Podraza-Kwiatkowska, 1975: Symbolizm i symbolika..., s. 304; P. Bąk, 1984: Gramatyka języka polskiego. Warszawa, Wiedza Powszechna, s. 317-318. 
Cóżem ja o miłości mówił! (WB 5)

Mniejsza, co mówiłem o miłości! (CP 15)

O, bracia, Bóg, któregom stworzył, był ludzkiem dziełem i obłędem, jako wszyscy bogowie. (WB 32)

O, bracia moi, ten bóg, którego ja stworzyłem, był ludzkim dziełem i obłędem, jak i wszyscy bogowie! (CP 44)

[...] kochamy życie nie dlatego, żeśmy do życia, lecz żeśmy do kochania przywykli. (WB 44)

[...] kochamy życie nie dlatego, że jesteśmy przyzwyczajeni do życia, lecz — do miłości. (CP 59)

[...] jam jest zwiastunem błyskawicy, jam jest ciężką kroplą z chmury: [...]. (WB 11)

[...] ja jestem zwiastunem piorunu i ciężką kroplą z chmury: [...]. (CP 22)

O tak, Zaratustro, prawdęś ty mi rzekł! Zaniku swego pożądałem, gdym ku wyżynom chęcią zmierzał, a tyś jest piorunem, którego wyczekiwałem! (WB 47) Tak, Zaratustro, mówisz prawdę. Pożądałem swej zguby, gdym dążył na wyżynę, a ty jesteś piorunem, na który czekałem! (CP 63)

Dobrze pochowałem cię w pustem drzewie, dobrzem od wilków cię ukrył. (WB 20) Dobrze cię pogrzebałem w pustem twem drzewie, dobrze cię uchroniłem przed wilkami. (CP 30)

W tym ostatnim zdaniu u Berenta alternacja zwykłej formy aglutynacyjnej (pochowałem) i formy złożonej z przemieszczoną końcówką osobową (dobrzem... ukrył) nie tylko wywołuje wrażenie podniosłości, lecz także wpływa na rytmizację wypowiedzi, która układa się w trzystopowy katalektyczny daktyl.

Berent często używa partykuły wzmacniającej - $\dot{z}(e)$ dołączonej do zaimków lub czasowników w zdaniach pytających i rozkazujących. Partykuła ta, zwykle sygnalizująca zdziwienie lub irytację mówiącego, dodaje tekstowi Tako rzecze Zaratustra emfazy, dostojeństwa i cech starodawności. Jak pisze Rajewicz $^{36}$, partykuła $-\dot{z}(e)$ z zaimkami występuje w przekładzie Lisieckiej i Jaskuły jako środek dyskretnie sugerujący dystans czasowy, natomiast tylko Berent łączy ją z czasownikami, osiągając mocniejszy efekt archaizacyjny: „Unikajcież tej złej woni! Uchodźcież od oparu tych ofiar ludzkich!” (WB 57),

36 Zob. T. Rajewicz, 2002: Dzieło i przekład w czasie..., s. 136. 
„Będęż ja dawał fałszywe świadectwo? Będęż cudzołożył?” (WB 28), „Niechże mię zwierzęta moje wiodą!" (WB 22) ${ }^{37}$.

Spotykamy też u Berenta archaiczną partykułę -ć, np.: „Zawszeć samość słucha i szuka” (WB 36), „barwnym dymem wydałoć mi się to” (WB 31), której brak u Pieńkowskich („Zawsze nasłuchuje Samo [sic!] i szuka” CP 49, „zdawało mi się dymem barwnym" CP 43).

Archaizacja w zakresie morfologii w Tako rzecze Zaratustra polega także na połączeniu niektórych przyimków (do, w, przez, dla) ze skróconą formą zaimka osobowego w bierniku: doń, weń, przezeń: „przezeń wszystko ginie” (WB 44), "Chwalebne jest dlań wszystko, co jest trudne do osiągnięcia” (WB 66) ${ }^{38}$. Dostrzegamy zwiększoną częstotliwość skróconych postaci zaimków dzierżawczych: me, twe, swe, ma, twa, swa oraz w przypadkach zależnych: mego, twego, swego etc., brzmiących podniośle, zwłaszcza gdy stoją za określanym rzeczownikiem: „I ze łzami memi idź w samotnię swą, o bracie!” (WB 74) ${ }^{39}$. Berent preferuje też starszy zaimek osobowy mię („Głód mię opada” WB 18), podczas gdy Pieńkowscy skłaniają się ku nowszemu mnie („Głód mnie napada” CP 28) ${ }^{40}$. Patyny dodaje tekstowi Berenta wyraz jako w dawnej funkcji przyłączającej porównanie: „Dusza ma nieporuszona jest i jasna jako wzgórza o poranku” (WB 14), „I cóż z mego rozumu! Pożądaż on wiedzy, jako lew karmu?” (WB 8), „Samotnik jest jako studnia głęboka" (WB 79) ${ }^{41}$.

W obszarze składni zwraca uwagę szyk przestawny, zwłaszcza opóźnione podanie orzeczenia - notabene charakterystyczne dla poezji Młodej Polski ${ }^{42}$. W cytowanym już zdaniu: „Błogosław kielich przepełniony, aby złotemi rozpłynął się strugi i twej świetności odblask wszędzie poroznosił" (WB 4) widoczne są następujące inwersje: rozdzielenie czasownikiem przydawki i określanego przez nią rzeczownika („aby złotemi rozpłynął się strugi”), odwrócenie ich kolejności („kielich przepełniony, twej świetności odblask”) oraz orzeczenie w zdaniu podrzędnym przesunięte na koniec, wzorem składni łacińskiej. Dla porównania,

37 Wersja Pieńkowskich: „Unikajcie tego złego zapachu! Idźcie precz od oparu tych ofiar ludzkich!” (CP 74), „Czy będę świadczył fałszywie? Czy będę cudzołożył?” (CP 40), „Niechaj mnie moje zwierzęta prowadzą!” (CP 31).

38 Pieńkowscy: „przez niego ginie wszystko” (CP 60), „Chwalebne jest to, co mu się wydaje trudnem" (CP 86).

39 Pieńkowscy: „Z mojemi łzami idź do swego osamotnienia, bracie mój” (CP 96).

40 Berentowskie zaimki drażniły Pieńkowskiego; wyśmiewał on przekład konkurenta jako „barokową groteskę libretową” (S. Pieńkowski, 1934: Jedwabiste zające i lisy biurkowe. „Myśl Narodowa”, nr 11, s. 148-151, tu: s. 149).

41 Pieńkowscy preferują neutralne jak: „Dusza moja spokojna jest i jasna, jak góry przed południem” (CP 24), „Mniejsza o mój rozum! Czy łaknie on wiedzy, jak lew pożywienia?” (CP 18), „Pustelnik jest jak studnia głęboka” (CP 103).

42 Zob. M. Podraza-Kwiatkowska, 1975: Symbolizm i symbolika..., s. 307. 
Pieńkowscy w tym samym miejscu rezygnują z inwersji: „Pobłogosław puhar [sic!], który chce się przechylić, aby zeń woda wypływała złociście i zanosiła wszędy odblask twojej słodyczy!” (CP 14) i podążają za tokiem składniowym oryginału: „Segne den Becher, welcher überfließen will, daß das Wasser golden aus ihm fließe und überallhin den Abglanz deiner Wonne trage!"

Archaizmy syntaktyczne w postaci końcowej lokalizacji orzeczenia powtarzają się we fragmentach nawiązujących do błogosławieństw z Kazania na górze ${ }^{44}$ :

Kocham tego, który złotemi słowy swe czyny uprzedza i zawsze więcej dotrzymuje, niźli był obiecał: gdyż on swego zaniku pragnie. (WB 11)

Kocham tego, który pracuje i odkrycia czyni, aby nadczłowiekowi dom wystawił oraz mierzwę, zwierzę i roślinę jemu zgotował: gdyż tako chce on swego zaniku. (WB 10)

U Pieńkowskich kolejność części zdania jest bardziej uporządkowana logicznie, a na kontekst biblijny wskazuje wyłącznie podniosły spójnik albowiem, kojarzący się ze stylistyką Pisma Świętego:

Kocham tego, kto złote słowa rozrzuca przed czynami i dotrzymuje zawsze więcej, niż obiecuje: albowiem ten pragnie swej zguby. (CP 21)

Kocham tego, kto pracuje i robi wynalazki, aby zbudować dom dla nadczłowieka i przygotować dlań ziemię, zwierzęta i rośliny: albowiem pragnie on swego upadku. (CP 20)

Przytoczone przykłady dobrze ilustrują kunszt Berenta w doborze środków archaizacyjnych. Tłumacz nader ostrożnie i oszczędnie korzysta bowiem z rozwiązań najłatwiejszych i najbardziej oczywistych - a do takich należy archaizm leksykalny albowiem. W czwartym podrozdziale Przedmowy Zaratustry, z którego pochodzą przytoczone cytaty, Nietzsche zawarł blisko tuzin zdań zbudowanych według schematu: Ich liebe Die, welche..., denn... (w liczbie pojedynczej: Ich liebe Den, der..., denn...). W tym miejscu Berent używa dziesięć razy neutralnego spójnika $g d y \dot{z}$, a podniosłego albowiem — zaledwie dwukrotnie. U Pieńkowskich proporcje są odwrotne: raz tylko występuje gdy $\dot{z}$,

43 F. Nietzsche, 1990: Also sprach Zarathustra. Ein Buch für alle und keinen. W: Idem: Das Hauptwerk. Bd. 3: Also sprach Zarathustra, Die Geburt der Tragödie, Jenseits von Gut und Böse. München, Nymphenburger, s. 1-363, tu: s. 6. Dalsze cytaty z tej pozycji oznaczam w tekście skrótem FN, po którym podaję numer strony.

44 Szczegółowo omawia je Ł.M. Plęs, 2010: Die biblischen sowie pseudobiblischen Seligpreisungen... 
za to albowiem - aż dziesięć razy ${ }^{45}$. Mechanicznie i w nadmiarze powtarzane albowiem sprawia wrażenie monotonii, a stylizacja Pieńkowskich wydaje się powierzchowna i jednowymiarowa, podczas gdy Berent osiąga efekt „biblizacji” środkami dużo bardziej wyszukanymi i urozmaiconymi.

Oprócz spójnika albowiem napotkamy u Berenta wiele innych archaizmów leksykalnych o konotacjach biblijnych: zali, zaprawdę, aliści, snadź, przeto, miłosierny, dzierżyć, ogrójec, łe ż ${ }^{46}$, niewiasta. Warto zatrzymać się przy tym ostatnim wyrazie, ponieważ jego dystrybucja w tekście świadczy o starannie przemyślanym podejściu tłumacza do możliwości archaizacyjnych polszczyzny. W mowie Zaratustry zatytułowanej w oryginale Von alten und jungen Weiblein, dotyczącej relacji kobiety i mężczyzny, pojawia się dwukrotnie neutralne (i dziś, i w czasach Nietzschego) słowo Frau (kobieta) i 29 razy Weib - powszechne w Biblii Lutra, dziś przestarzałe lub obraźliwe (odpowiednik polskiego wyrazu baba). Notabene autorzy wersji z roku 1999, Lisiecka i Jaskuła, konsekwentnie posługują się w tym fragmencie leksemem niewiasta (LJ 84-86), uznawszy go za powszechnie rozpoznawalny biblizm. Od synonimu kobieta odstępują całkowicie, choć w nowszych spolszczeniach Pisma Świętego leksem ten zajmuje niekiedy miejsce niewiasty z przekładu Wujka ${ }^{47}$. Pieńkowscy oddają das Weib jako kobieta, ograniczając niewiastę do znaczenia 'starej kobiety'. I tak, rozmówczyni Zaratustry - w oryginale „das alte Weiblein” — to u Pieńkowskich „stara niewiasta”, a tytuł przemowy brzmi: O starych i młodych niewiastach (CP 97). Berent natomiast zdaje się unikać wyrazu niewiasta tak samo, jak Lisiecka i Jaskuła rezygnują ze słowa kobieta. Tytuł Von alten und jungen Weiblein tłumaczy zatem O starej i młodej kobietce (WB 75), zaś interlokutorka Zaratustry to „stara babina”, „starka” (WB 75) i „stara” (WB 77) ${ }^{48}$. Niewiasta pojawia się tylko w jednym miejscu, w parze z leksemem mąż, który w tym kontekście - w znaczeniu 'mężczyzna' - brzmi dostojnie i uroczyście: „Ku wojnie wychowany ma być mąż, niewiasta zaś ku wytchnieniu wojownika” (WB 76) ${ }^{49}$. Wszędzie poza tym

45 Nawet tam, gdzie oryginał nie uzasadnia użycia tego spójnika, ponieważ u Nietzschego są dwa osobne zdania niepołączone relacją przyczynowości.

46 U Pieńkowskich odpowiadają im leksemy neutralne, np.: „ogrójec małżeństwa” (WB 80) - „ogród małżeństwa” (CP 104), „Łeż to!” (WB 54) — „To kłamstwo!” (CP 71), „Zaliś jest zwycięzcą” (WB 80) — „Czy jesteś owym zwycięzcą” (CP 104).

47 Zob. U. Topczewska, 2014: „Niewiasta” czy „kobieta”? Zwrot kulturowy w polskich przekładach biblijnych. „Biuletyn Polskiego Towarzystwa Językoznawczego”, nr 70, s. $155-165$.

48 W wersji Lisieckiej i Jaskuły tytuł brzmi O starowinkach i młódkach (LJ 84), a stara kobieta nazywana jest na przemian „starowinką" i „staruszką”.

49 „Der Mann soll zum Kriege erzogen werden und das Weib zur Erholung des Kriegers” (FN 70); u Pieńkowskich: „Mężczyzna powinien być wychowany dla wojny, kobieta - dla odpoczynku wojownika" (CP 98).

\begin{tabular}{l|l} 
PLS.2021.11.01.08 | s. $12 \mathrm{z} 23$
\end{tabular} 
antytezę Mann - Weib tłumaczy Berent jako mężczyzna - kobieta ${ }^{50}$, a więc bez nacechowania stylistycznego ${ }^{51}$. Na tle wielokrotnie powracającej neutralnej pary mężczyzna - kobieta biblijne konotacje raz tylko użytego słowa niewiasta rysują się wyjątkowo wyraźnie, wzmocnione dodatkowo przez bezpośrednie sąsiedztwo komplementarnego archaizmu mąż. Omówiony fragment uzmysławia, że Berent nie tylko archaizuje, lecz miejscami także modernizuje przekład ${ }^{52}$, z potencjalnych ekwiwalentów (kobieta, niewiasta, białogłowa) wybierając najbardziej nowoczesny - i w jego epoce, i dzisiaj. Paradoksalnie, taka punktowa, wybiórcza modernizacja leksykalna zdaje się służyć uwypukleniu całościowej, archaizującej koncepcji przekładu.

\section{Poetycki idiolekt Berenta}

Wśród formacji leksykalnych typowych dla pisarskiego stylu Berenta, obecnych zarówno w Tako rzecze Zaratustra, jak i w Próchnie oraz Oziminie, wypada wspomnieć o rzeczownikach odsłownych. Zastępują one inną konstrukcję gramatyczną, odbieraną jako bardziej naturalna, poprawna bądź przyjemniejsza dla ucha. Według Hultberga odgrywają one u Berenta podwójną rolę. Jako sformułowania rozmyślnie „niezręczne”, naruszające zasady eufonii i poprawności językowej stanowią element stylu ekspresjonistycznego ${ }^{53}$. Oprócz tego mogą „nazywać zjawiska, na określenie których nie istnieje w języku zwykły rzeczownik" ". W większości przypadków bardziej naturalne byłoby zastąpienie ich zwykłym rzeczownikiem, ku czemu skłaniają się pozostali tłumacze:

Niebezpieczne to przejście, niebezpieczne podróże, niebezpieczne wstecz poglądanie, niebezpieczne trwożne zachwianie i zatrzymywanie się. (WB 9)

50 Przykładowo: „Dwuch [sic!] rzeczy pragnie prawdziwy mężczyzna: niebezpieczeństwa i igraszki. Przeto pożąda kobiety, jako najniebezpieczniejszej igraszki” (WB 76) - u Pieńkowskich: „Dwojga chce prawdziwy mężczyzna: niebezpieczeństwa i gry. Dlatego chce on kobiety, jako najniebezpieczniejszej zabawki” (CP 98).

51 Dlatego można powiedzieć, że rozwiązaniu Lisieckiej i Jaskuły: mężczyzna - niewiasta brak jednorodności stylistycznej, ponieważ zestawiają oni leksem współczesny (neutralny) $\mathrm{z}$ archaizmem, np.: „Mężczyzna winien być chowany dla wojny, a niewiasta dla odpoczynku wojownika" (LJ 85).

52 Modernizację wzmiankuje M. Kopij (2005: F. Nietzsche w literaturze i publicystyce..., s. 222), jednak bez przytaczania konkretnych przykładów.

53 Zob. P. Hultberg, 1969: Styl wczesnej prozy..., s. 227.

54 Ibidem, s. 165.

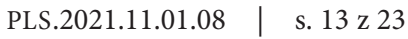


Niebezpiecznym skokiem, niebezpiecznem przejściem, niebezpiecznem spojrzeniem wstecz, niebezpiecznym dreszczem i postojem. (CP 20) $)^{55}$

W odgadywaniu i przemilczaniu mistrzem powinien być przyjaciel: [...]. (WB 65)

Przyjaciel powinien być mistrzem w odgadywaniu i milczeniu: [...]. (CP 83)

$\mathrm{W}$ domysłach i umiejętności milczenia przyjaciel winien być mistrzem; [...].

(LJ 73$)^{56}$

W tych przykładach rzeczowniki odczasownikowe w Tako rzecze Zaratustra to kalki z Nietzschego ${ }^{57}$. Niekiedy jednak można je uzasadnić nie tyle wystąpieniem analogicznej formacji w oryginale, ile raczej względami instrumentacji głoskowej, np. „Atem des Alleinseins” (FN 67) to u Berenta „tchnienie osamotnienia” (WB 72), choć Atem to „oddech”, a więc rzeczownik zwykły, a nie gerundium ${ }^{58}$. Odmienna wydaje się motywacja tego zjawiska w zdaniach:

i widziałem, jako wielkie zasmucenie nawiedziło ludzi. (WB 161)

Aby się ono [światło - K.L.] nie zdusiło w tem zasmętnieniu! (WB 162) ${ }^{60}$

Skądże ta łza na mem oku i to serca zmiękczenie nagłe? (WB 126) ${ }^{61}$

Rzeczowniki odsłowne: zasmucenie, zasmętnienie, zmiękczenie nazywają pewien stan ducha (smutek) bądź cechę (miękkość) jako wynik trwającego jakiś czas procesu, podkreślają więc dynamikę i zmianę. Predylekcję Berenta do tego typu formacji szczegółowo opisują Hultberg i Paszek.

Inna osobliwość stylistyczna, którą - jak zauważa Hultberg - Berent przenosi z własnej prozy do przekładu, to alternacja czasu teraźniejszego i przeszłego. Nawet tam, gdzie Nietzsche nieprzerwanie stosuje narracyjny czas Präteritum, Berentowi zdarzają się „przeskoki” do teraźniejszości:

55 „Ein gefährliches Hinüber, ein gefährliches Auf-dem-Wege, ein gefährliches Zurückblicken, ein gefährliches Schaudern und Stehenbleiben" (FN 11).

56 „Im Erraten und Stillschweigen soll der Freund Meister sein” (FN 60).

57 Język niemiecki dopuszcza nominalizację każdej części mowy, traktowanej wówczas jako rzeczownik rodzaju nijakiego i pisanej wielką literą.

58 Por. „oddech tego sam na sam” (CP 94), „oddech samotności” (LJ 81).

59 Por. „i widziałem wielki żal, który spadł na ludzi” (LJ 175) — „Und ich sahe [sic!] eine große Traurigkeit über die Menschen kommen” (FN 146).

60 Por. „Aby go ten żal nie zdławił!” (LJ 176) — „Daß es mir nicht ersticke in dieser Traurigkeit!" (FN 147).

61 Por. „Gdzie podziały się łzy z moich oczu i miękkość mojego serca?” (LJ 138) — „Wohin kam die Träne meinem Auge und der Flaum meinem Herzen?” (FN 114). 
Gdy, powracając z mej samotni, po raz pierwszy przechodziłem przez ten most: nie dowierzałem oczom własnym: spoglądam, patrzę i mówię wreszcie: $[\ldots]^{62}$. (WB 167-168)

Obróciłem klucze, próbuję podźwignąć wrota: mozolę się. Lecz jeszczem ani na szczelinę rozewrzeć ich nie zdołał: $[\ldots]^{63}$. (WB 164)

Powodem takich decyzji mogła być chęć wzmocnienia dynamiki akcji, która w przywołanych miejscach dzięki alternacji czasów zdaje się toczyć bardziej wartko niż u Nietzschego. Intensyfikując elementy narracji, tłumacz uwypukla niejako fakt, że Zaratustra to nie tylko „statyczne” monologi i aforyzmy.

Hultberg wyróżnia jeszcze jedną cechę stylu Berenta, widoczną w Oziminie: chiazm, stosowany dla urozmaicenia rytmu zdań i uniknięcia monotonnych paralelizmów ${ }^{64}$. Chwyt ten obserwujemy w Zaratustrze dość często:

[...] przeskoczy on swój cień własny - i zaprawdę! we własne skoczy on słońce. (WB 140)

[er wird] über seinen eigenen Schatten springen - und, wahrlich! hinein in seine Sonne. (FN 127)

Rzecz nową pragnie tworzyć szlachetny i nową cnotę. (WB 48)

Neues will der Edle schaffen und eine neue Tugend. (FN 45)

Nie zawsze jednak zabieg ten występuje tam, gdzie Nietzsche odwraca porządek zdania, np.: „tem jest wasza ostatnia nadzieja i upojenie ostatnie” (WB 135) „so ist es eure letzte Hoffnung und Trunkenheit” (FN 122). Ten rodzaj inwersji wprowadza podniosły ton współbrzmiący ze stylizacją biblijną — widoczny, jeśli porównamy na przykład Berentowski chiazm „ciałem jestem i duszą” (WB 34; „Leib bin ich und Seele”, FN 34) z nienacechowaną wersją Pieńkowskich: „Jestem ciałem i duszą" (CP 48).

62 „Und als ich aus meiner Einsamkeit kam und zum ersten Male über die Brücke ging: da traute ich meinen Augen nicht und sah hin, und wieder hin, und sagte endlich: [...]" (FN 151).

63 „Und ich drückte den Schlüssel und hob am Tore und mühte mich. Aber noch keinen Fingerbreit stand es offen" (FN 148). Przykład podaję za: P. Hultberg, 1969: Styl wczesnej prozy..., s. 208.

64 Zob. P. Hultberg, 1969: Styl wczesnej prozy..., s. 174-175. 


\section{Na styku idiolektu Berenta i poetyki Młodej Polski: neologizmy, instrumentacja głoskowa}

W Tako rzecze Zaratustra dostrzegamy neologizmy i chwyty słowotwórcze, które trudno jednoznacznie przypisać Berentowi, gdyż te same lub podobne słowa znajdziemy u innych pisarzy Młodej Polski. Mamy tu i posępnicę ${ }^{65}$ Żeromskiego, i Tetmajerowską osmętnicę ${ }^{66}$, i przywołujący echa Leśmiana przysłówek bezobłocznie ${ }^{67}$. Jerzy Paszek wskazuje w przekładzie liczne wyrazy utworzone według schematów słowotwórczych typowych dla Berenta, wykorzystanych w Próchnie, a potem w Żywych kamieniach jako chwyt archaizacyjny ${ }^{68}$. Wymienić tu trzeba między innymi rzeczowniki $\mathrm{z}$ formantami -ca $\left(\right.$ podziemcy $\left.{ }^{69}\right)$ lub -iciel (gardziciel), przymiotniki z morfemem przyrostkowym -owy (włosiennicowy ${ }^{70}$, torturowe $\left.k o ł o^{71}\right)$. Liczne są w tłumaczeniu Berenta przykłady modyfikacji słowotwórczych: urwa $^{72}$, omięknac ${ }^{73}$, wypary ${ }^{74}$, opłoty ${ }^{75}$, ciemnia. Ten ostatni wyraz, w dopełniaczu krótszy niż standardowa alternatywa ciemności, pozwala uzyskać wyrazisty rytm: „lecz kto się ciemni mej nie trwoży” (WB 127), nieobecny w oryginale ${ }^{76}$. Wiele idiosynkratycznych tworów tego typu ma na celu instrumentację głoskową, oddanie lub kompensację paronomazji i aliteracji Nietzschego. Przykładowo, nagromadzenie spółgłosek wybuchowych $p, t$ we

65 WB 166. Tu w oryginale neutralny rzeczownik „Traurigkeit” (FN 150), u Lisieckiej i Jaskuły: „żal” (LJ 179).

66 Uczniowie Zaratustry czekają, „zali [...] nie zleczy swej osmętnicy” (WB 163), u Lisieckiej i Jaskuły: „czy [...] nie ozdrowieje z melancholii” (LJ 176). Nietzsche używa tu podniosłej frazy: „ob er [...] genesen sei von seiner Trübsal” (FN 147).

67 „Nauczyliśmy się [...] bezobłocznie uśmiechać” (WB 199), w oryginale: „[wir lernten] wolkenlos hinab lächeln” (FN 181). U Nietzschego mimo metaforyczności całej frazy sam przysłówek wolkenlos należy do języka potocznego (dziś usłyszymy go np. w prognozie pogody) i tym tropem podążają Lisiecka i Jaskuła: „uczyliśmy się [...] bezchmurnych uśmiechów” (LJ 213).

68 Zob. J. Paszek, 1976: Styl powieści..., s. 84-85.

69 WB 144 - „die Unterweltlichen” (FN 130), „istoty podziemne” (LJ 156).

70 „Dla wszystkich włosiennicowych ciała gardzicieli” (WB 231) — „allen bußhemdigen Leib-Verächtern” (FN 208), „dla włosieniczych wzgardzicieli ciała” (LJ 243).

71 „[Jesteście] torturowem kołem dla wszelkich myśli” (WB 144) — „[ihr seid] aller Gedanken Gliederbrechen” (FN 130), „łamiecie ogniwa wszystkich myśli” (LJ 156).

72 WB 172 - „Abhang” (FN 156), „urwisko” (LJ 186).

73 WB 179 - „mürbe werden” (FN 162), „skruszeć” (LJ 193).

74 WB 133 - „Dampf” (FN 121), „opary” (LJ 146).

75 „Chcę okół myśli swych opłoty mieć” (WB 231-232) — „ich will Zäune um meine Gedanken haben” (FN 209), „chcę mieć ogrodzone myśli” (LJ 243).

76 „Wer sich vor meinem Dunkel nicht scheut” (FN 116), „kto nie lęka się mojej ciemności” (LJ 140). 
frazie „ptaki zabłąkane w polotach” (WB 144) nie tylko sugeruje łopot ptasich skrzydeł, lecz służy także jako ekwiwalent paronomazji w oryginale: „verflogene Vögel” (FN 130).

Tłumaczenie Berenta cechuje wielka dbałość o warstwę brzmieniową, niekiedy kosztem sensu. I tak, sekwencja instrumentacyjna „troska, groza i dno rzeczy” (WB 199) zdominowana przez „głęboką” samogłoskę o zastępuje niejako potrójny rym inicjalny: „Gram und Grauen und Grund” (FN 181), ale nie informuje o tym, że Grund to jeden z najważniejszych terminów filozoficznych Nietzschego ${ }^{77}$. Podobna konstrukcja z pięciokrotnym $o$ : „stróżem nocy i grobów stałem się, tam na samotnej opoce" (WB 163) również kompensuje frazę zawierającą paronomazję i figurę etymologiczną: „Zum Nacht- und Grabwächter war ich worden, dort auf der einsamen Berg-Burg des Todes” (FN 147). Instrumentacja głoskowa Berenta bywa też wyrazistsza niż u Nietzschego: „zachwytliwe natchnienie” (WB 133) brzmi bardziej „ekstatycznie” niż neutralne „Verzückung” (FN 121) ${ }^{78}$, zaś nagromadzenie samogłosek nosowych we frazie „otuleni w grubą osmętnicę udręki” (WB 49) oddaje nastrój melancholii bardziej sugestywnie niż wyrażenie „eingehüllt in dicke Schwermut” (FN 47), niewyróżniające się pod względem akustycznym ${ }^{79}$. Berent wynajduje kunsztowne odpowiedniki onomatopei Nietzschego, np.: „Z łoskotem, poświstem i skowytem załamała się trumna i zionęła tysiąckrotnym chichotem” (WB 164) — „Und im Brausen und Pfeifen und Schrillen zerbarst der Sarg und spie tausendfältiges Gelächter aus” (FN 148) ${ }^{80}$. Bywa, że potęguje efekty dźwiękowe, np.: „Po tylekroć brała mnie ochota złotym zygzakiem błyskawicy przygwoździć je do nieba” (WB 200, chodzi o chmury) — „Und oft gelüstete mich, sie mit zackichten Blitz-Golddrähten festzuheften” (FN 182) ${ }^{81}$. U Berenta mamy tu do czynienia z synestezją: kumulacja „zgrzytających” spółgłosek ź, dź i „syczących” s, $z$ wywołuje brzmieniowe skojarzenie z gwałtownym, błyskawicznym ruchem w celu pochwycenia jakiegoś przedmiotu; wyrazy złoty i błyskawica sugerują zarazem wrażenia wzrokowe. Duża częstotliwość instrumentacji głoskowej, tendencja

77 Wersja Lisieckiej i Jaskuły: „zgryzot[a], zgroz[a] i grunt” (LJ 212) oddaje zarówno aliterację, jak i sugestię, że chodzi o pojęcie filozoficzne, ponieważ tłumacze starają się przekładać Grund konsekwentnie jako grunt (zob. S. Lisiecka, Z. Jaskuła, 1999: Od tłumaczy..., s. 434).

78 U Lisieckiej i Jaskuły: zachwycenie (LJ 147). Paszek (1976: Styl powieści..., s. 49) lokalizuje Berentowski neologizm zachwytliwy w Oziminie.

79 Por. „otuleni grubą melancholią” (CP 66), „spowici ciężkim smutkiem” (LJ 57).

80 Lisiecka i Jaskuła tworzą tu onomatopeję może bardziej wyrazistą niż Berent: „A w huku, gwiździe i świście przeraźliwym rozpękła się trumna i plunęła tysiąckrotnym śmiechem" (LJ 177). U Berenta jednak dodatkowy walor poetycki wnosi niezwykła metafora "zionąć chichotem”, rozbijająca utartą kolokację zionąć ogniem.

81 Por. „Wielekroć brała mnie chęć, by okalać je złotymi drutami błyskawic” (LJ 213). 
do rytmizacji tekstu, efekty dźwiękonaśladowcze i synestezyjne cechują cały przekład Berenta i są także charakterystyczne dla poetyki Młodej Polski.

\section{Wnioski}

Z przeprowadzonej analizy wypływają wnioski historycznoliterackie, dotyczące miejsca Tako rzecze Zaratustra w twórczości Wacława Berenta, oraz teoretyczne, obejmujące perspektywę odbioru i perspektywę przekładanego dzieła.

Ustaliwszy, że Tako rzecze Zaratustra zyskał swój kształt pod wpływem zarówno preferencji estetycznych epoki, jak i stylu własnego Berenta, można się pokusić o umiejscowienie tego tekstu w twórczości autora Oziminy. Według Zdzisława Jaskuły tłumaczenie Berenta jest ściśle związane z Próchnem, oba dzieła oświetlają się wzajemnie i stanowią ideowo-poetycką całość. Dlatego współautor pierwszego przekładu „po Berencie” skłonny jest traktować Tako rzecze Zaratustra nie jako przekład sensu stricto, ale jako „quasi-oryginał”, naznaczony niepowtarzalną sygnaturą polskiego pisarza ${ }^{82}$. Jednak Berent wykorzystuje w Zaratustrze środki wyrazu znane nie tylko z Próchna, lecz także z Oziminy, a nawet z późniejszych Żywych kamieni ${ }^{83}$. O ile można ustalić, że warszawski prozaik pracował nad przekładem Nietzschego już w roku 1894, czyli przed wydaniem Próchna, o tyle trudno zweryfikować hipotezę Jerzego Paszka, jakoby pisarz ukształtował swój własny idiolekt pod wpływem pracy translatorskiej ${ }^{84}$. Skłaniałabym się ku przypuszczeniu, że między Tako rzecze Zaratustra a Próchnem zachodziło raczej sprzężenie zwrotne. Zaratustra nie jest katalizatorem pisarstwa własnego Berenta, nie jest też ogniwem pośrednim między Próchnem a Oziminą. Za sprawą wyrazistej archaizacji różni się od wszystkich innych tekstów Berenta, a jednocześnie zawiera w sobie cząstkę artystycznych środków wyrazu każdego z nich. Taka charakterystyka Zaratustry wpisywałaby się, jak sądzę, w nowsze ujęcia badawcze, podkreślające „elementy spójności w spuściźnie literackiej autora Próchna” ${ }^{\text {(5) }}$ i traktujące ją, mimo różnic między poszczególnymi tekstami, jako pewne kontinuum.

Na pewno translację Berenta adekwatnie określa zaproponowana przez Monikę Kaczorowską (badającą przekłady Barańczaka) formuła „przekładu jako

82 Zob. Z. Jaskuła, 2007: Der ambivalente Status einer neuen Übersetzung. Polnische Zufälle um Friedrich Nietzsches „Also sprach Zarathustra“. W: B. Chołuj, U. Räther, hrsg.: Grenzerfahrungen literarischer Übersetzung. Berlin, Logos, s. 68-83, tu: s. 80-82.

83 Zob. J. Paszek, 1976: Styl powieści..., s. 83.

84 Zob. ibidem, s. 85, 94.

85 W. Gruchała, 2007: Architekt prozy. Retoryczna analiza stylu wybranych powieści Wacława Berenta. Kraków, Collegium Columbinum, s. 23.

\begin{tabular}{l|l} 
PLS.2021.11.01.08 | s. $18 \mathrm{z} 23$
\end{tabular} 
kontynuacji twórczości własnej” - co oznacza, że tłumacz „w pracy przekładowej posługuje się tymi samymi co w sytuacji tworzenia własnej poezji środkami artystycznymi"86, jednak zmodyfikowanymi na potrzeby interpretacji poetyki oryginału. U Berenta modyfikacja ta polega na pogłębionej - w porównaniu z oryginałem - stylizacji biblijnej i młodopolskiej, co naraziło tłumacza na zarzut zmanierowania. Jak wykazała analiza, autor Próchna wystrzega się decyzji archaizacyjnych łatwych, banalnych i powierzchownych. Nierzadko wręcz unika stereotypowych biblizmów - po to, by jego stylizacja, sięgająca głęboko w strukturę tekstu, dała przekonujący efekt artystyczny. Z kolei cechy młodopolszczyzny - inwersje, zabiegi słowotwórcze, rytmizacja, onomatopeje - mają uzasadnienie w nietzscheańskim postrzeganiu języka i artysty, tworzącego dzieło na nowo zgodnie $\mathrm{z}$ własną, niczym nieskrępowaną wolą ${ }^{87}$. Stanisław Pigoń, pisząc o nieustannym wypróbowywaniu przez Berenta wciąż nowych środków wyrazu, widzi w owym dążeniu, charakterystycznym dla twórczej indywidualności autora Próchna, „wytrwałe mocowanie się z podstępnym wrogiem każdego pisarza stylisty: z manieryzmem"88. W moim przekonaniu przekład Nietzschego jest świadectwem tych zmagań i dowodem, że Berent wyszedł z nich zwycięsko. Język Młodej Polski nie jest u niego wyrazem manieryzmu, lecz świadomą decyzją wypływającą z odczytania oryginału.

Tako rzecze Zaratustra zaświadcza „młodopolską” lekturę dzieła Nietzschego z jej — jak pisze Marta Kopij - uwrażliwieniem na liryczno-muzyczne środki wyrazu ${ }^{89}$. Odczytanie Berenta można nazwać hiperbolizacją, polegającą na przerysowaniu biblijno-archaizacyjnych elementów tłumaczonego dzieła. Równie istotne jest skupienie na warstwie brzmieniowej, którą cechuje naddatek instrumentacji dźwiękowej wobec tej użytej przez Nietzschego. Argumenty te pozwalałyby dostrzec w tłumaczeniu Berenta cechy symbolistycznego modelu przekładu wyodrębnione przez Tamarę Brzostowską-Tereszkiewicz $^{90}$ - jedynego z modeli translacji modernistycznych, który jest „bezpośrednią pochodną historycznego nurtu poetyckiego

86 M. Kaczorowska, 2011: Przekład jako kontynuacja twórczości własnej. Na przykładzie wybranych translacji Stanisława Barańczaka z języka angielskiego. Kraków, Universitas, s. 267.

87 Tak właśnie, „po nietzscheańsku”, interpretuje postawę translatorską Berenta M. Kopij, 2005: F. Nietzsche w literaturze i publicystyce..., s. 223.

88 S. Pigoń, 1969: Trzy słowa o Wacławie Berencie. W: Idem: Wiąanka historycznoliteracka. Warszawa, PIW, s. 327-342, tu: s. 329.

89 Zob. M. Kopij, 2005: F. Nietzsche w literaturze i publicystyce..., s. 222.

90 Główna jego cecha to eksponowanie fonicznych walorów oryginału, zob. T. Brzostowska-Tereszkiewicz, 2015: Przekład modernistyczny: modele i opozycje. W: W. Bolecki, W. Soliński, M. Gorczyński, red.: Współczesne dyskursy konfliktu: literatura - językkultura. Warszawa, IBL, s. 45-90, tu: s. 65-68. 
modernizmu"91. Okazuje się jednak, że styl epoki nie determinuje całkowicie przekładu: $w$ tym samym czasie powstały bowiem dwa zupełnie różne tłumaczenia Zaratustry, ilustrujące odmienne podejścia translatorskie. Koncepcja Marii i Stanisława Pieńkowskich zasadza się na przekonaniu o prostocie, jasności i zwięzłości języka Zaratustry oraz o jego współczesnym charakterze ${ }^{92}$. Tłumacze zdają się nie dostrzegać wyrafinowanej poetyki Nietzschego, koncentrują się na słownikowych ekwiwalentach pojedynczych słów i na poprawnym formułowaniu zdań. Ich przekład dla dzisiejszego czytelnika brzmi bardziej współcześnie i zrozumiale niż wersja Berenta, jednak nie daje żadnego pojęcia o estetyce dzieła. Z kolei Berent skupił się na oddaniu walorów poetycko-muzycznych prozy Nietzschego, co już krytyków młodopolskich skłoniło do oceny, jakoby autor Zaratustry „,przyswojony został naszej literaturze jako literat, filozof gubi

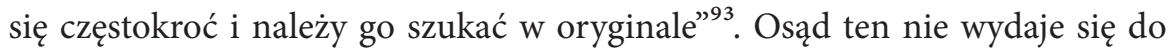
końca słuszny. Filozoficzność Also sprach Zarathustra nie polega przecież ani na dyscyplinie i klarowności wywodu, ani na precyzji aparatu pojęciowego. Wynika raczej z filologicznej gry wieloznacznością słów oraz z literackiego sposobu obrazowania, w którym dochodzą do głosu sceptycyzm i krytyczny ogląd kategorii ugruntowanych w filozofii. Tak pojętą myśl filozoficzną Nietzschego prezentuje właśnie tłumaczenie Berenta.

Perspektywa przekładanego dzieła nasuwa refleksję, że w przypadku tekstu Nietzschego, zarazem filozoficznego i literackiego, alternatywa „Dichter oder Denker” jest błędna; autor Also sprach Zarathustra to „Dichter und Denker”. Nietzsche, filozof kultury, dla przekazania swoich myśli używał środków poetyckich. Uważany za protoplastę egzystencjalistów, którzy wypowiadali się poprzez literaturę (dramaty Sartre’a, powieści Camusa), otwiera tłumaczom dwie drogi: poetyckość języka i myśl filozoficzną. Tę drugą wybrali Pieńkowscy, jednak obrana przez nich formuła redukująca i upraszczająca oryginał okazała się wrogiem przekładu. Berent starał się połączyć obie możliwości, przy czym na pierwszy plan wysuwają się walory estetyczne jego tłumaczenia; przetrwało ono próbę czasu właśnie jako dzieło poetyckie. Trzeba było niemal stu lat, by następcy pokusili się o próbę połączenia poezji i filozofii w kolejnym przekładzie.

91 Ibidem, s. 68.

92 Por. S. Pieńkowski, 1922: Nie tak mówił Zaratustra..., s. 5.

93 Recenzja z roku 1907, cyt. za: M. Kopij, 2005: F. Nietzsche w literaturze i publicystyce..., s. 211. 


\section{Literatura}

Bąk P., 1984: Gramatyka języka polskiego. Warszawa, Wiedza Powszechna.

Brückner A., 1989: Słownik etymologiczny języka polskiego. Warszawa, Wiedza Powszechna.

Brzostowska-Tereszkiewicz T., 2015: Przekład modernistyczny: modele i opozycje.

W: W. Bolecki, W. Soliński, M. Gorczyński, red.: Współczesne dyskursy konfliktu: literatura - jezzyk - kultura. Warszawa, IBL, s. 45-90.

Cieszkowski M., 2004: „Tako rzecze Zaratustra” czy „To rzekł Zaratustra” - uwag kilka o polskich tłumaczeniach niepokornego tekstu. „Recepcja - Transfer Przekład", t. 2, s. 109-120.

Gruchała W., 2007: Architekt prozy. Retoryczna analiza stylu wybranych powieści Wacława Berenta. Kraków, Collegium Columbinum.

Hultberg P., 1969: Styl wczesnej prozy fabularnej Wacława Berenta. I. Sieradzki, tłum. Wrocław-Warszawa-Kraków, Zakład Narodowy im. Ossolińskich. Jaskuła Z., 2007: Der ambivalente Status einer neuen Übersetzung. Polnische Zufälle um Friedrich Nietzsches „Also sprach Zarathustra“. W: B. Chołuj, U. Räther, hrsg.: Grenzerfahrungen literarischer Übersetzung. Berlin, Logos, s. 68-83.

Kaczorowska M., 2011: Przekład jako kontynuacja twórczości własnej. Na przykładzie wybranych translacji Stanisława Barańczaka z języka angielskiego. Kraków, Universitas.

Kaulhausen M.H., 1977: Nietzsches Sprachstil: gedeutet aus seinem Lebensgefühl und Weltverhältnis. München-Wien, Oldenbourg.

Klemensiewicz Z., 1999: Historia języka polskiego. Warszawa, PWN.

Kopij M., 2005: Friedrich Nietzsche w literaturze i publicystyce polskiej lat 18831918. Struktura recepcji. Poznań, Wydawnictwo Poznańskie.

Lisiecka S. et al., 2000: Rozmowa 1: O czytaniu Nietzschego. „Tytuł”, z. 4, s. 70-76. Lisiecka S., Jaskuła Z., 1999: Od tłumaczy. W: F. Nietzsche: To rzekł Zaratustra. Książka dla wszystkich i dla nikogo. S. Lisiecka, Z. Jaskuła, tłum. Warszawa, PIW, s. 431-435.

Lisiecka S., Jaskuła Z., 2000: Między filologia a filozofią. O tłumaczeniu „Zaratustry” Nietzschego. „Tytuł”, z. 4, s. 54-69.

Makowiecki A.Z., 1992: Młoda Polska. W: A. Brodzka et al., red.: Słownik literatury polskiej XX wieku. Wrocław-Warszawa-Kraków, Zakład Narodowy im. Ossolińskich, s. 651-664.

Nietzsche F., 1901: Tak mówił Zaratustra. Książka dla wszystkich i dla nikogo. M. Cumft, S. Pieńkowski, tłum. Warszawa, Wydawnictwo Władysława Okręta.

Nietzsche F., 1990: Tako rzecze Zaratustra. Książka dla wszystkich i dla nikogo. W. Berent, tłum. Warszawa, Bis. 
Nietzsche F., 1990: Also sprach Zarathustra. Ein Buch für alle und keinen. W: Idem: Das Hauptwerk. Bd. 3: Also sprach Zarathustra, Die Geburt der Tragödie, Jenseits von Gut und Böse. München, Nymphenburger, s. 1-363.

Nietzsche F., 1999: To rzekł Zaratustra. Książka dla wszystkich i dla nikogo. S. Lisiecka, Z. Jaskuła, tłum. Warszawa, PIW.

Nycz R., 1997: Homo irrequietus. Nietzscheanizm w twórczości Wacława Berenta.

W: Idem: Język modernizmu. Prolegomena historycznoliterackie. Wrocław, Leopoldinum, s. 263-312.

Paszek J., 1976: Styl powieści Wacława Berenta. Katowice, Uniwersytet Śląski.

Pieńkowski S., 1922: Nie tak mówił Zaratustra. „Gazeta Warszawska”, nr 239, s. 5-6.

Pieńkowski S., 1934: Jedwabiste zające i lisy biurkowe. „Myśl Narodowa”, nr 11, s. $148-151$.

Pigoń S., 1969: Trzy słowa o Wacławie Berencie. W: Idem: Wiazanka historycznoliteracka. Warszawa, PIW, s. 327-342.

Plęs Ł.M., 2010: Die biblischen sowie pseudobiblischen Seligpreisungen in „Also sprach Zarathustra" im Spiegel der Übersetzungsversuche ins Polnische und Englische. „Acta Universitatis Lodziensis. Folia Germanica”, nr 6, s. 95-107. Plęs Ł.M., 2012: Friedrich Nietzsche - Dichter oder Denker? „Acta Universitatis Lodziensis. Folia Germanica", nr 8, s. 36-49.

Podraza-Kwiatkowska M., 1975: Symbolizm i symbolika w poezji Młodej Polski. Kraków, Wydawnictwo Literackie.

Rajewicz T., 2002: Dzieło i przekład w czasie. O języku polskich przekładów dzieła Fryderyka Nietzschego „Also sprach Zarathustra”. „Recepcja - Transfer Przekład", t. 1, s. 127-140.

Rajewicz T., 2005: Stylizacja biblijna „Zaratustry” Friedricha Nietzschego w przekładach na język polski. W: Język trzeciego tysiąclecia 3: zbiór referatów z konferencji, Kraków, 4-7.03.2004. T. 2: M. Piotrowska, red.: Konteksty przekładowe. Kraków, Tertium, s. 99-106.

Topczewska U., 2014: „Niewiasta” czy „kobieta”? Zwrot kulturowy w polskich przekładach biblijnych. „Biuletyn Polskiego Towarzystwa Językoznawczego”, nr 70, s. 155-165. 


\section{Katarzyna Lukas \\ Tako rzecze Zaratustra Wacława Berenta: młodopolska maniera czy nowatorski eksperyment?}

STRESZCZENIE | Artykuł dotyczy cech stylistycznych Tako rzecze Zaratustra Wacława Berenta - przekładu Also sprach Zarathustra Friedricha Nietzschego. Analiza pokazała, że tłumacz wykorzystuje trzy kody językowo-literackie: styl Młodej Polski, własny poetycki idiolekt oraz język staropolskiej Biblii jako wzorzec archaizacyjny. Ze wzorców tych korzysta jednak wybiórczo i krytycznie, unikając manierystycznych rozwiązań translatorskich. Wyeksponowanie archaizacji i walorów brzmieniowych pozwala upatrywać w tekście Berenta cechy symbolistycznego modelu przekładu, a Tako rzecze Zaratustra jako eksperyment językowy wpisuje się w kontinuum twórczości własnej polskiego pisarza.

SŁOWA KLUCZOWE | przekład, Młoda Polska, archaizacja, Friedrich Nietzsche, Wacław Berent

\section{Katarzyna Lukas \\ Wacław Berent's Tako rzecze Zaratustra \\ (Translation of Friedrich Nietzsche's Also sprach Zarathustra): Young-Poland-Mannerism or an Innovative Experiment?}

SUMMARY | The paper analyzes the stylistic features of the Polish translation of Friedrich Nietzsche's Also sprach Zarathustra made by the Polish writer Wacław Berent (1905). It demonstrates that the translator draws on three linguistic-literary codes: the style of the poetry of "Young Poland", Berent's own poetic idiolect, and the old Polish language of the Bible as a source of archaisms. However, the translator uses these stylistic patterns in a selective and critical way, avoiding mannerist solutions in his translation. As Berent reinforces archaisms and the original's audial qualities, his text may be considered an example of symbolist translation. Being an innovative linguistic experiment, the translation can be viewed as a continuation of the Polish writer's own literary work.

KEYWORDS | translation, Young Poland, archaism, Friedrich Nietzsche, Wacław Berent

KATARZYNA LUKAS | dr hab., prof. Uniwersytetu Gdańskiego, pracuje w Instytucie Filologii Germańskiej UG. Absolwentka germanistyki UAM. Autorka monografii: Fremdheit - Gedächtnis - Translation: Interpretationskategorien einer kulturorientierten Literaturwissenschaft (2018); Obraz świata i konwencja literacka w przekładzie. O niemieckich tłumaczeniach dzieł Adama Mickiewicza (2008; wydanie niemieckie: Das Weltbild und die literarische Konvention als Übersetzungsdeterminanten, 2009) oraz artykułów z zakresu literatury niemieckiej, teorii przekładu, komparatystyki literackiej i problematyki pamięci kulturowej. Współredaktorka tomów zbiorowych, m.in. Translation im Spannungsfeld der „cultural turns“(2013). Wraz z Andrzejem Kątnym i Czesławą Schatte wydaje serię „Danziger Beiträge zur Germanistik” w wydawnictwie Peter Lang. 